\title{
EFFECT OF CYTOSTATIC AGENTS ON EXPRESSION LEVELS OF HUMAN BETA-DEFENSINS-1-4 IN A431 AND MCF-7 CELL LINES
}

\author{
O.S. Zubenko*, D.O. Semeniuk, I.O. Starenka, P.V. Pogribnyy \\ R.E. Kavetsky Institute of Experimental Pathology, Oncology and Radiobiology, NAS of Ukraine, \\ Kyiv 03022, Ukraine
}

The aim of the study was to analyze an effect of cytostatic agents of different mechanism of action on expression levels of human beta-defensins-1-4 (hBD-1-4) in cultured human cancer cell lines. Materials and Methods: Expression levels of hBD-1-4 mRNA were assessed using qPCR in human epidermoid carcinoma A431 cells and human breast adenocarcinoma MCF7 cells treated with cisplatin, methotrexate, doxorubicin or vincristine at the IC20 concentrations. Results: The cytostatic agents with different mechanisms of action affected differently expression of hBDs, dependent on the cell line. Mostly, cytostatic agents suppressed significantly expression of hBDs. In contrast, vincristine caused significant up-regulation of $h B D-1(12$ fold, $p<0.05)$ and $h B D-4(2$ fold, $p<0.05)$ in MCF7, and doxorubicin significantly enhanced expression of $h B D-3(2$ fold, $p<0.05)$ and $h B D-4(>10$ fold, $p<0.05)$ in A431 cells. Conclusion: The results of this pilot study show that expression levels of $h B D-1-4$ may be altered upon treatment with cytostatic agents depending on nature of cells.

Key Words: A431 cells, MCF7 cells, human beta-defensins, cytostatic agents.

Human defensins are cationic cysteine-rich antimicrobial peptides and represent important components of innate immune system. Depending on their structure, in particular, disulfide bonding, defensins are classified into the subfamilies of alpha- and beta-defensins (human beta-defensins - hBDs). Originally defensins were described as antibacterial peptides, but further research showed that they have a wide range of functions in the human body. As the molecules capable to link innate and adaptive immunity, defensins are ascribed to the family of alarmins, molecules involved in danger signaling; it is supposed that they may play a role in the tumor microenvironment [1]. Apart from this, some defensins are capable to cause tumor cell lysis and exert pro- or antitumorigenic and angiogenic activities [2] . Hypothetically, beta-defensins could be capable to influence the cancer cell sensitivity to cytototoxic agents. To address this issue, we have analyzed the influence of cytostatic agents of different mechanisms of action on the expression of beta-defensins in cultured human cancer cell lines.

\section{MATERIALS AND METHODS}

Cell lines. In the experiment, we used human epidermoid carcinoma A431 and human breast adenocarcinoma MCF7 cell lines. The cell lines were obtained from the Bank of Cell Lines from Human and Animal Tissues of the R.E. Kavetsky Institute of Experimental Pathology, Oncology and Radiobiology, NAS of Ukraine. A431 and MCF7 cells were cultured

Submitted: June 10, 2017.

*Correspondence: E-mail: Oleksiy2017Z0S@gmail.com

Abbreviations used: CP - cisplatin; DOX - doxorubicin; FBS - fetal bovine serum; hBD - human beta-defensin; MET - methotrexate; MTT - 3-(4,5-dimethylthiazol-2-yl)-2,5-diphenyltetrazolium; qPCR - quantitative polymerase chain reaction; VIN - vincristine. in DMEM medium supplemented with $10 \%$ fetal bovine serum (FBS), in a humidified atmosphere with $5 \% \mathrm{CO}_{2}$ at $37^{\circ} \mathrm{C}$.

Analysis of cell viability (MTT-assay). To evaluate the effect of cytotoxic agents on cell viability, MTT method was used [3]. In short, tumor cells were seeded in 96 -well plates $\left(7 \cdot 10^{3}\right.$ cells per well) and incubated with cytotoxic agents (doxorubicin, cisplatin, vincristine, methotrexate in a wide range of concentrations $(0.01-5 \mathrm{mg} / \mathrm{ml}$; $0.25-50 \mathrm{mg} / \mathrm{ml} ; 0.025-5 \mathrm{mg} / \mathrm{ml} ; 2.5-500 \mathrm{mg} / \mathrm{ml}$, respectively) in DMEM medium, with the addition of $2.5 \%$ FBS for $24 \mathrm{~h}$. Then the cells were treated with 3-(4,5-dimethylthiazol-2-yl)-2,5-diphenyltetrazolium (MTT) reagent by standard protocol. Colorimetric reaction was evaluated using a Plate Analyzer StarFax 2100 at a wavelength of $492 \mathrm{~nm}$.

Isolation of total RNA. Isolation of total RNA from cultured cells was carried out using the Trizol reagent. The concentration of RNA was determined by spectrophotometry at a wavelength of $260 \mathrm{~nm}$ using a NanoDrop 1000 machine. The quality of RNA was assessed by electrophoresis in $1 \%$ agarose gels.

Quantitative real-time PCR. Expression of beta-defensins in A431 and MCF7 cells treated with cytotoxic agents was analyzed by quantitative polymerase chain reaction ( $\mathrm{QPCR}$ ) using specific primers. Design of primers was performed using Oligo 6.31 program.

The reaction was carried out in a volume of $20 \mathrm{ml}$, containing $10 \mathrm{ml}$ mixture of reagents Maxima SYBR Green/ROX qPCR Master Mix, 0.5 pmol of each specific primer, $1 \mathrm{ml}$ of cDNA obtained in the reverse transcription reaction and demineralized water. The reaction was performed on Thermocycler 7500 RealTime PCR System. The reaction conditions and sequences of specific primers are shown in the Table 1. 
Table 1. Conditions for quantitative real time PCR

\begin{tabular}{|c|c|c|}
\hline Gene & Primer & Conditions \\
\hline \multirow[t]{3}{*}{ Beta-actin } & F: GAAATCGTGCGTGACATTAA & Denaturation $-94^{\circ} \mathrm{C}, 15 \mathrm{~s}$ \\
\hline & R: CCAGACAGCACTGTGTTGG & $\begin{array}{l}\text { Annealing/Elongation - } \\
59^{\circ} \mathrm{C}, 60 \mathrm{~s}\end{array}$ \\
\hline & & Number of cycles - 40 \\
\hline \multirow[t]{3}{*}{$H B D-1$} & F: CTCCCCAGTTCCTGAAATCCT & Denaturation $-94^{\circ} \mathrm{C}, 15 \mathrm{~s}$ \\
\hline & R: GCCTGTGAGAAAGTTACCACC & $\begin{array}{l}\text { Annealing }-57^{\circ} \mathrm{C}, 30 \mathrm{~s} \\
\text { Elongation }-72^{\circ} \mathrm{C}, 30 \mathrm{~s}\end{array}$ \\
\hline & & Number of cycles - 40 \\
\hline \multirow[t]{4}{*}{$H B D-2$} & F: TGAAGCTCCCAGCCATCAG & Denaturation $-94^{\circ} \mathrm{C}, 15 \mathrm{~s}$ \\
\hline & R: ATCGCCTATACCACCAAAAACAC & Annealing $-57^{\circ} \mathrm{C}, 30 \mathrm{~s}$ \\
\hline & & Elongation $-72{ }^{\circ} \mathrm{C}, 30 \mathrm{~s}$ \\
\hline & & Number of cycles - 40 \\
\hline \multirow[t]{2}{*}{$H B D-3$} & R: CCTGTTTTTGGTGCCTGTTCC & Denaturation $-94^{\circ} \mathrm{C}, 15 \mathrm{~s}$ \\
\hline & R: CTTTCTTCGGCAGCATTTTTCG & $\begin{array}{l}\text { Annealing }-57^{\circ} \mathrm{C}, 30 \mathrm{~s} \\
\text { Elongation }-72^{\circ} \mathrm{C}, 30 \mathrm{~s}\end{array}$ \\
\hline \multirow[t]{3}{*}{$H B D-4$} & F: GACTTGTGCTGCTATTAGCCA & Denaturation $-94^{\circ} \mathrm{C}, 15 \mathrm{~s}$ \\
\hline & R: CGATTCAGTAAGCTCTCATCC & Annealing $-57^{\circ} \mathrm{C}, 30 \mathrm{~s}$ \\
\hline & & $\begin{array}{l}\text { Elongation }-72{ }^{\circ} \mathrm{C}, 30 \mathrm{~s} \\
\text { Number of cycles }-40\end{array}$ \\
\hline
\end{tabular}

The threshold fluorescence level was determined using software SDS software V.1.3.1. Gene expression was normalized by the reference gene (beta-actin), comparison of gene expression was performed by 2 - $\delta \delta$ Ct method.

Statistical analysis. To determine the significance of the differences between the data groups Student's $t$-criterion was used. The differences were considered significant at $p<0.01$ for MTT test and $p<0.05$ for $q$ PCR. The data are presented as $\mathrm{M} \pm \mathrm{m}$.

\section{RESULTS AND DISCUSSION}

In present research, we aimed to analyze the effect of cytostatic agents commonly used in clinical practice, i.e. cisplatin, doxorubicin, vincristine, and methotrexate on expression of hBDs mRNAs in two cancer cell lines, A431 and MCF7. These cytostatic agents are known to cause cytotoxic effects via different mechanisms: 1) cisplatin, inorganic water-soluble platinum complex, acts as DNA crosslinker, disturbing replication and translation; 2) doxorubicin, anthracycline antibiotic, intercalates DNA and blocks its replication; 3) methotrexate, folate analog, is an antimetabolite blocking the synthesis of thymidine, purine and pyrimidine; and 4) vincristine is an alkaloid capable to bind with microtubules and prevents the formation of mitotic spindles, consequently blocking cell mitosis. To study effects of these agents on hBDs expression in vitro, first of all, we have determined minimal concentrations of the cytotoxic drugs causing a significant decrease of tumor cell viability using MTT assay. These concentrations corresponding to IC20 values (Table 2) were used in our further experiments. Breast cancer cells were much more sensitive to the studied cytostatics than epidermoid carcinoma cells.

Table 2. IC20 values for cytostatic agents estimated in culture of A431 and MCF7 cells

\begin{tabular}{lcc}
\hline \multicolumn{1}{c}{ IC20 agent } & $\mathrm{A} 431, \mu \mathrm{g} / \mathrm{ml}$ & $\mathrm{MCF} 7, \mu \mathrm{g} / \mathrm{ml}$ \\
\hline Doxorubicin & $42 \pm 3$ & $0.19 \pm 0.02$ \\
Cisplatin & $4.4 \pm 1.5$ & $0.13 \pm 0.02$ \\
Methotrexate & $60 \pm 9$ & $1.8 \pm 0.2$ \\
Vincristine & $0.4 \pm 0.2$ & $0.16 \pm 0.02$ \\
\hline
\end{tabular}

Expression of hBD-1-4 mRNAs in the A431 and MCF7 cell line treated with minimal effective concentrations of cytotoxic agents was assessed with qPCR (Fig. 1, 2). As it has been shown, expression of hBD-1 gene significantly decreased after incubation of both cell lines with cisplatin, methotrexate and doxorubicin, especially in A431 cells (by $80 \pm 20$ times in cisplatin-treated $A 431$ cells, and $67 \pm 6$ times in methotrexate-treated A431, $p<0.05$ ) (Fig. 1, 2, a). In contrary, treatment with vincristine did not cause significant influence on the expression of hBD-1 gene in A431 cells, but significantly stimulate its expression in MCF7 cells (up to $12 \pm 0.2$ fold, $p<0.05$ ) (Fig. 2, a). Expression of hBD-2 gene drastically fall in A431 cells treated with any of mentioned agents: by $28 \pm 5$ fold, $120 \pm 30$ fold, 200 fold, and $150 \pm 30$ fold in the cells treated with doxorubicin, methotrexate, cisplatin, and vincristine, respectively $(p<0.05)$ (Fig. $1, b)$. Interestingly, in MCF7 cells the cytostatic agents had no effect of the level of hBD-2 expression as well as expression of hBD-3 gene. Interestingly, in A431 cells expression of hBD-3 gene increased more than 2 fold and expression of hBD-4 more than 10 fold after treatment with doxorubicin $(p<0.05)$. Regarding hBD-3 and hBD-4 expression in MCF7 cells treated with cytostatic agents, significant differences were detected just in 2 cases:
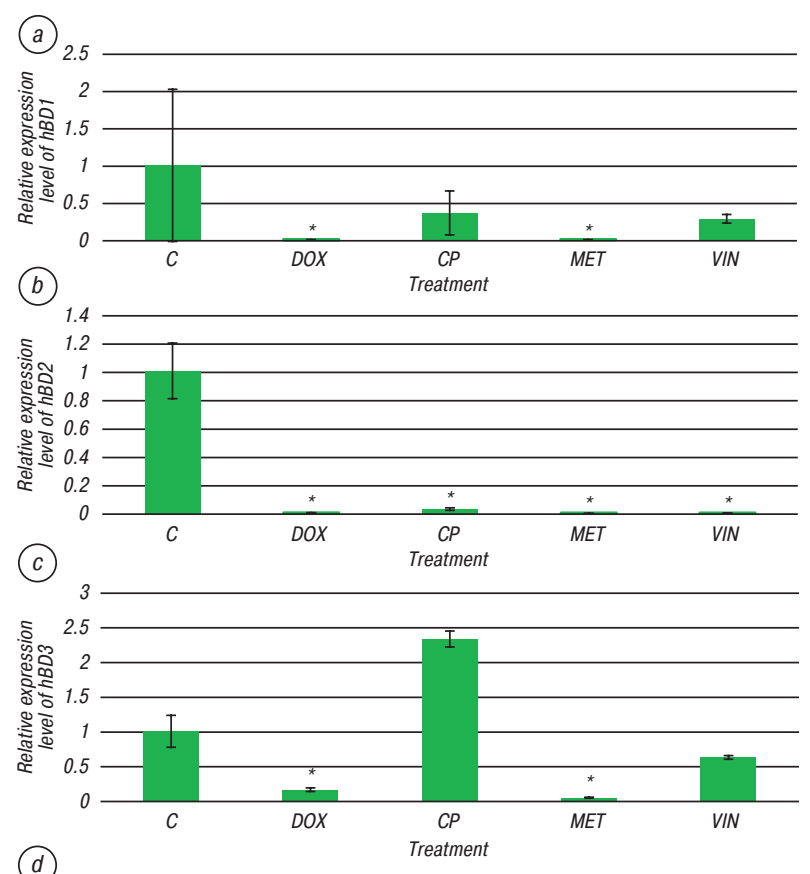

(d)

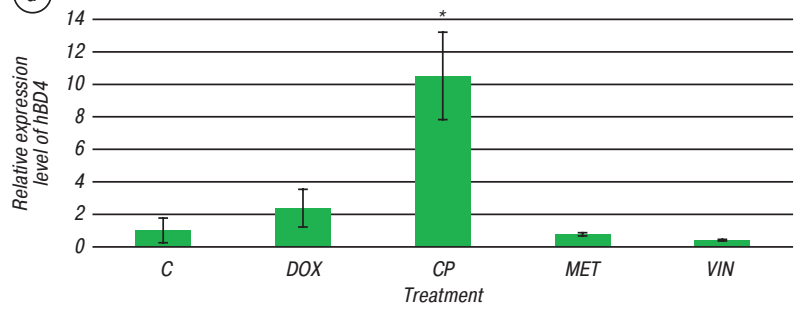

Fig. 1. Effect of cytotoxic agents on the expression of hBD1 (a), hBD-2 (b), hBD-3 (c) and hBD-4 (d) in A431 cell line. C - control sample; MET - $60 \mathrm{mg} / \mathrm{ml}$ methotrexate; DOX $-42 \mathrm{mg} / \mathrm{ml}$ doxorubicin; $\mathrm{CP}-4.4 \mathrm{mg} / \mathrm{ml}$ cisplatin; $\mathrm{VIN}-0.4 \mathrm{mg} / \mathrm{ml}$ vincristin sulfate. The data are presented as $\mathrm{M} \pm \mathrm{m}, \mathrm{n}=2$.

*The difference is significant compared with the control, $p<0.05$ 

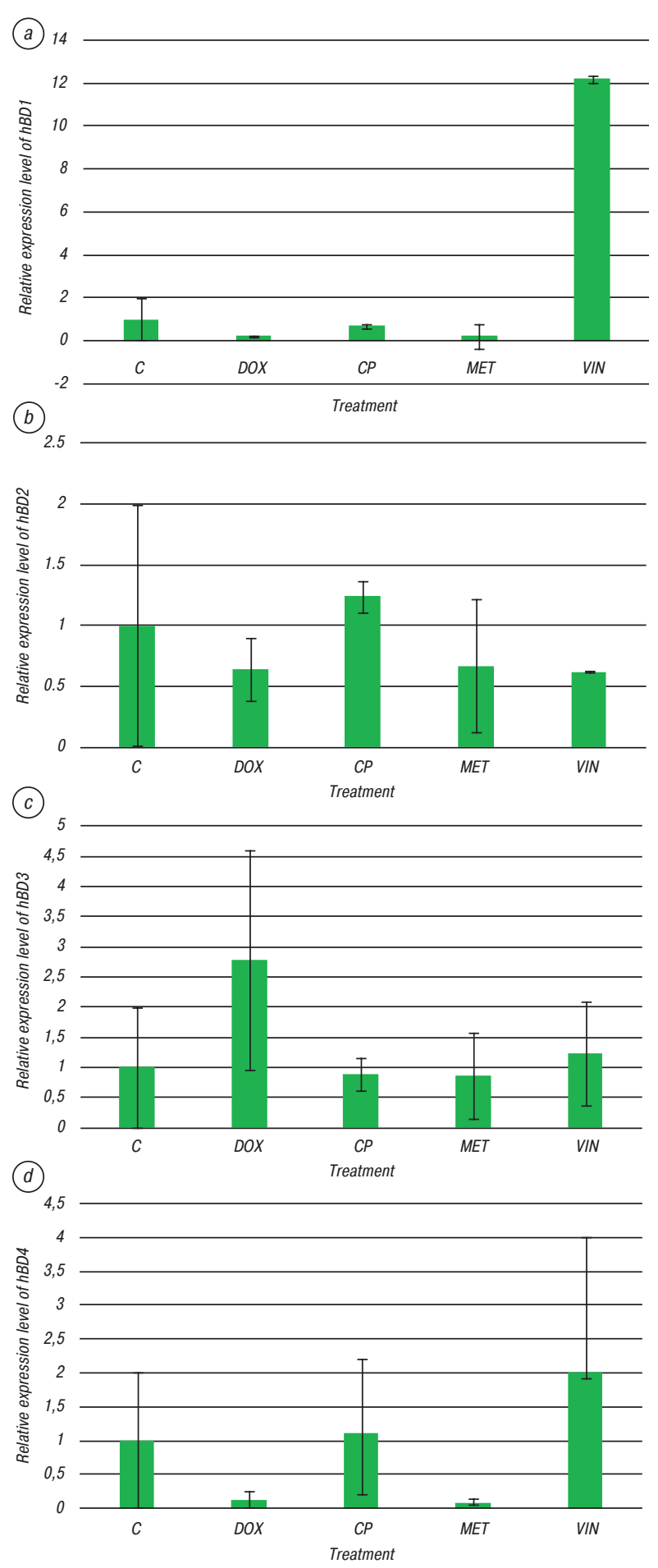

Fig. 2. Effect of cytotoxic agents on the expression of hBD1 (a), hBD-2 (b), hBD-3 (c) and hBD-4 (d) in MCF7 cell line. C - control sample; MET - $1.8 \mathrm{mg} / \mathrm{ml}$ methotrexate; DOX $-0.19 \mathrm{mg} / \mathrm{ml}$ doxorubicin; $\mathrm{CP}-0.13 \mathrm{mg} / \mathrm{ml}$ cisplatin; $\mathrm{VIN}-0.16 \mathrm{mg} / \mathrm{ml}$ vincristin sulfate. The data are presented as $M \pm m, n=2$.

*The difference is significant compared with the control, $p<0.05$

expression of hBD-4 genes was significantly downregulated by MET (by $13 \pm 2$ fold, $p<0.05$ ) and significantly up-regulated by vincristine (by $2.0 \pm 0.1$ fold, $p<0.05$ ) (Fig. 2, $d$ ).

The obtained data have shown that the cytostatic agents with different mechanisms of action differentially affect expression of hBDs dependent on cell line.
Mostly, cytostatic agents suppress expression of hBDs, however vincristine caused significant up-regulation of hBD-1 and hBD-4 genes in breast cancer cells, while doxorubicin significantly enhanced expression of hBD-3 and hBD-4 genes in A431 cells. It is tempting to speculate that the mentioned above effects of particular hBDs up-regulation caused by vincristine in MCF-7 cells and doxorubicin in A431 cells could point on possible protective functions of these defensins in the cells undergoing cytotoxic treatment.

Unfortunately, the studies in this field are scarce. For example, it was reported that doxorubicin inhibits the expression of hBD-3 in oropharyngeal cancer cells, possibly, via activation of the transcription factor p53, which is a repressor of hBD-3 gene transcription [4]. Another study reported that methotrexate is capable to block induction of hBD-2 expression in hFOB cells [5]. An interesting observation has been done regarding alpha-defensins expression in breast tumors. In this research, proteomic and genetic profiling of pretreatment breast cancer biopsies demonstrated that expression of alpha-defensins and a microtubuleassociated protein MAP2 is associated with pathologic complete response to therapy with taxanes, antimicrotubule agents, in the patients with breast cancer [6]. So, alpha-defensins could be considered as the markers of sensitivity of breast tumors to taxane-based therapy.

In conclusion, our pilot study has revealed that cytostatic agents with different mechanism of action differentially affect expression of beta-defensins-1-4 in two cultured tumor cell lines. Expression of hBD-2 gene was the most sensititve for cytotoxic treatments and significantly decreased in the presence of any of them in A431 cells. Expression of hBD-4 gene was the most protected against cytotoxic influence, moreover, it significantly increased under the action of doxorubicin in A431 cells and vincristine in MCF7 cells. Further study will possibly help to understand whether beta-defensins, especially, hBD-4 could play a role in the protection of cancer cells against cytotoxic agents or in their sensibilization to cytostatic drugs.

\section{REFERENCES}

1. Coffelt SB, Scandurro AB. Tumors sound the alarmin(s). Cancer Res 2008; 68: 6482-5.

2. Weinberg A, Jin G, Sieg S, McCormick TS. The Yin and Yang of human beta-defensins in health and disease. Front Immunol 2012; 3: 294.

3. Mosmann T. Rapid colorimetric assay for cellular growth and survival: application to proliferation and cytotoxicity assays. Immunol Methods 1983; 65: 55-63.

4. DasGupta T, Nweze EI, Yue H, et al. Human papillomavirus oncogenic E6 protein regulates human $\beta$-defensin 3 (hBD3) expression via the tumor suppressor protein p53. Oncotarget 2016; 7: 27430-44.

5. Varoga D, Tohidnezhad M, Paulsen F, et al. The role of human $\beta$-defensin-2 in bone. J Anat 2008; 213: 749-57.

6. Bauer JA, Chakravarthy AB, Rosenbluth JM, et al. Identification of markers of taxane sensitivity using proteomic and genomic analyses of breast tumors from patients receiving neoadjuvant paclitaxel and radiation. Clin Cancer Res 2010; 16: $681-90$. 